\section{To: (Receiving organization) \\ Distribution}

5. Proj./Prog./Dept./Div.:

TWRS

8. Originator Remarks:

Approval/Release

11. Receiver Remarks:

11A. Désiggr Baseline Document?

[] Yes 3. From: (originating organization) TWRS SE Risk Management \& Modeling
6. Design Authority/ Design Agent/Cog. Engr.:
P. E. Porter

4. Related EDT No.:

$N / A$

7. Purchase Order No.:

$N / A$

9. Equip./Component No.:

$\mathrm{N} / \mathrm{A}$

10. System/Bldg./Facility:

$N / A$

12. Major Assm. Dwg. No.:

$N / A$

13. Permit/Permit Application No.: $N / A$

14. Required Response Date: $\mathrm{N} / \mathrm{A}$

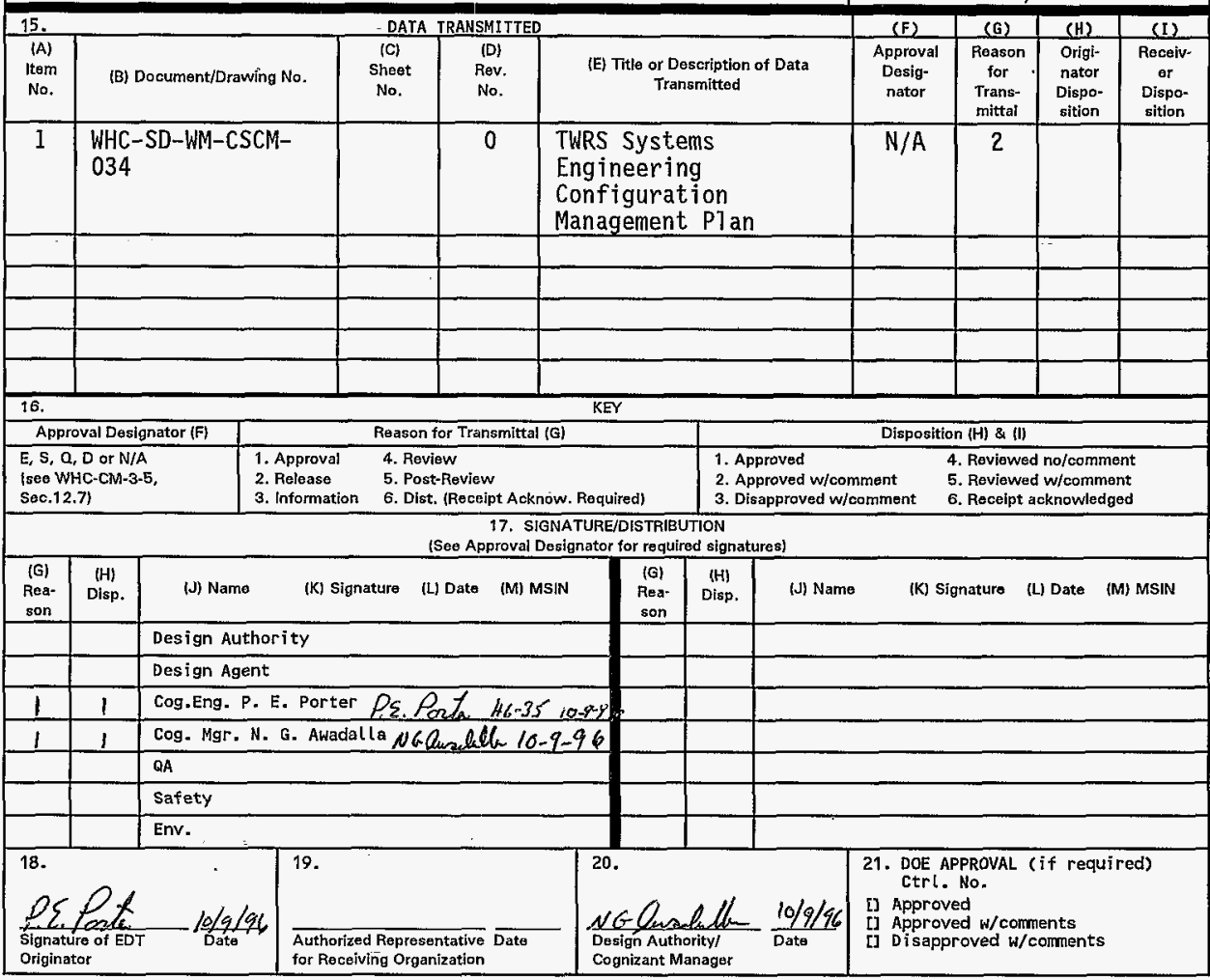

$B D-7400-172-2(05 / 96)$ GEF097 


\title{
TWRS Systems Engineering Software Configuration Management Plan
}

\author{
P. E. Porter
}

WHC, Richland, WA 99352

U.S. Department of Energy Contract DE-AC06-87RL10930

EDT/ECN: 618219

UC: 905

Org Code: 74450

Charge Code: DIMGB

B\&R Code: 101M02080s Tota1 Pages: 19 EW3120075

Key Words: software, configuration management, systems engineering

Abstract: This plan delineates the requirements for control of software developed and supported by the Tank Waste Remediation System (TWRS) Technical Integration organization. The information contained in this plan shall assist employees involved with software modification and configuration contral.

TRADEMARK DISCLAIMER. Reference herein to any specific commercial product, process, or service by trade name, trademark, manufacturer, or otherwise, does not necessarily constitute or imply its endorsement, recommendation, or favoring by the United States Government or any agency thereof or its contractors or subcontractors.

Printed in the United States of Arnerica. To obtain copies of this document, contact: WHC/BCS Document Control Services, P.0. Box 1970, Mailstop H6-08, Richland WA 99352, Phone (509) 372-2420. Fax (509) 376-4989.
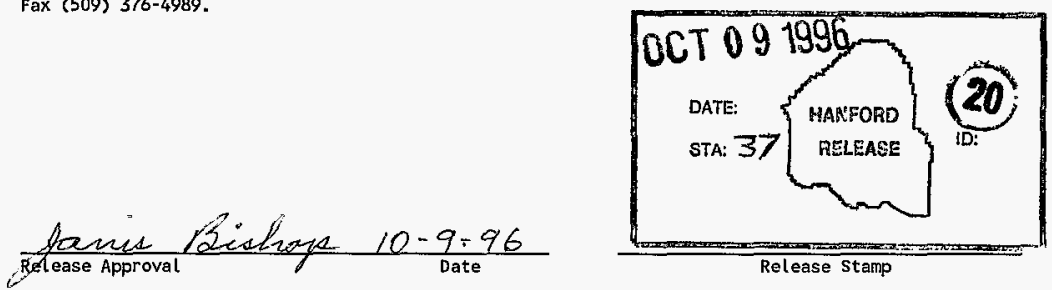

\section{Approved for Public Release}


WHC-SD-WM-CSCM-034, Rev. 0

TWRS SYSTEMS ENGINEERING

SOFTWARE CONFIGURATION MANAGEMENT PLAN 
ACRONYMS AND ABBREVIATIONS ................ iv

1.0 INTRODUCTION . . . . . . . . . . . . . . . . . . 1

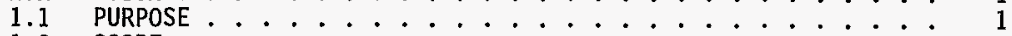

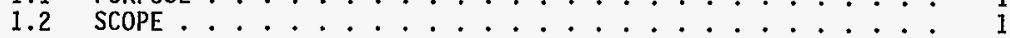

2.0 RESPONSIBILITIES . . . . . . . . . . . . . . . 2

2.1 SYSTEM ADMINISTRATOR ............... 2

2.2 CHANGE CONTROL ADMINISTRATOR $\therefore \ldots . . \cdots 2$

2.3 PROJECT LEAD . . . . . . . . . . . . 2

2.4 USERS AND REQUEST INITIATORS $\ldots \ldots$

2.5 POLICIES AND PROCEDURES . . . . . . . ...... 3

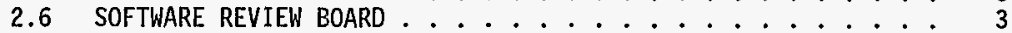

3.0 SOFTWARE CONFIGURATION ITEMS IDENTIFICATION ......... 4

3.1 CONFIGURATION ITEM SCOPE CRITERIA . . . . . . . 4

3.2 SOFTWARE CONFIGURATION DOCUMENTATION $\ldots \ldots$

3.3 SOFTWARE IDENTIFICATION AND VERSION CONTROL . . . . . 4

3.3 .1 Bug Fixes .................. 4

3.3.2 Minor Revisions ............... 4

3.4 BACKUP AND RECOVERY.............

4.0 SOFTWARE CHANGE CONTROL ................. 6

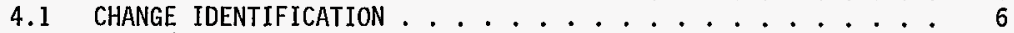

4.2 SCREENING $\ldots \ldots \ldots \ldots$

4.3 DEVELOPMENT . . . . . . . . . . . . 6

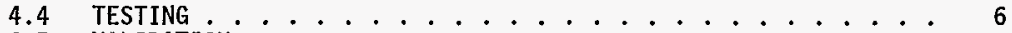

4.5 VALIDATION $\ldots \ldots \ldots \ldots \ldots \ldots \ldots \ldots$

4.6 IMPLEMENTATION $\ldots \ldots \ldots$

5.0 STATUS ACCOUNTING . . . . . . . . . . . . . 7

5.1 RECORDS ........................ 7

5.2 TRACKING $\ldots \ldots \ldots \ldots \ldots \ldots$

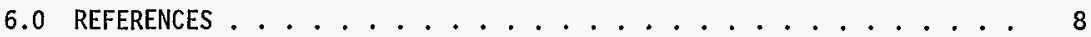

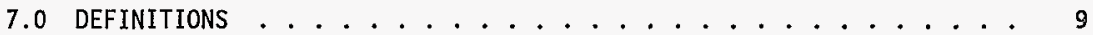


WHC-SD-WM-CSCM-034, Rev. 0

\section{ACRONYMS AND ABBREVIATIONS}

CCA Change Control Administrator

CM Configuration Management

SA System Administrator

SCMP Software Configuration Management Plan

SCR System Change Request

SDLC Software Development Life Cycle

SRB Software Review Board

SRN System Revision Number

WHC Westinghouse Hanford Company 
WHC-SD-WM-CSCM-034, Rev. 0

\subsection{IRTRODUCTION}

\subsection{PURPOSE}

This document delineates the requirements for control of software developed and supported by the Tank Waste Remediation System (TWRS) Technical Integration organization. The information contained in this plan shall assist employees involved with software modification and configuration control.

\subsection{SCOPE}

This document applies to all software elected to be configuration managed by the TWRS Technical Integration Organization. 


\subsection{RESPONSIBILITIES}

- TWRS Technical Integration is the owner and key user organization of the software configuration items covered by this plan.

- TWRS Technical Integration manages all changes in administrative and user procedures and training.

- TWRS Technical Integration is responsible for ensuring that the software

- engineer is following the configuration management process correctly. This is usually monitored by the System Administrator in conjunction with the Project Lead over software development.

- TWRS Management Systems provides configuration management support for the configuration items covered by this plan.

\subsection{SYSTEM ADMINISTRATOR}

The System Administrator (SA) shall maintain the adherence to documented procedures for system software for daily operation and maintenance. The SA approves completion of testing on the software change requests (SCR). The SA maintains the software Project Workbook.

\subsection{CHANGE CONTROL ADMINISTRATOR}

The Change Control Administrator (CCA) administers the TWRS Technical Integration Organization Software change control process. The CCA assigns unique system change request identifiers and tracks changes to configuration managed software. The Change Control Administrator and the System Administrator can be the same person.

\subsection{PROJECT LEAD}

The Project Lead over the software development has the responsibility of ensuring that the configuration management process is being followed correctly and overseeing the software change process..-

\subsection{USERS AND REQUEST INITIATORS}

The Users and Request Initiators are responsible for requesting changes in accordance with this pIan, including correct initiation of SCRs. 
WHC-SD-WM-CSCM-034, Rev. 0

\subsection{POLICIES AND PROCEDURES}

This $\mathrm{plan}$ has been developed using the procedures documented in WHC-CM-3-10, Software Practices, as a guidetine. This $p$ lan functions as part of the TWRS Configuration Management Program defined in WHC-SD-WM-CM-013, TWRS Configuration Management Program Plan.

\subsection{SOFTWARE REVIEW BOARD}

A software review board (SRB) may be established to provide advisory recommendations pertaining to future software revisions. This board shall be formed with representative users, SA, and the Project Lead. 
WHC-SD-WM-CSCM-034, Rev. 0

\subsection{SOFTWARE CONFIGURATION ITEMS IDENTIFICATION}

\subsection{CONFIGURATION ITEN SCOPE CRITERIA}

Software that is used to store, manipulate, transmit, or which otherwise handles and may impact the validity of TWRS Technical Baseline information shall be placed under configuration management. Software outside this scope shall be separately evaluated for CM control.

\subsection{SOFTWARE CONFIGURATION DOCUMENTATION}

Documentation should be developed according to the guidelines set forth in WHC-CM-3-10. The Project Lead and System Administrator shall determine the proper set of documentation based on the scope and use of the software.

\subsection{SOFTHARE IDENTIFICATION AND VERSION CONTROL}

All software versions shall maintain a major, a minor, and a bug-fix, version number (e.g., Version 5.43). The 5 is the major version number, the 4 is the minor version number, and the 3 is the bug-fix version number.

A11 version changes, are identified (summarized) on a SCR form. Changes that are in the same category can be grouped together on one SCR form. ATI changes, except editorial, must be documented using the SCR form. However, the initiation and approval authority for the SCR depends on the category of the change. The approval path for each category of changes shall be determined on a case-by-case basis. All changes should be reviewed for consistency with the TWRS Systems Engineering Software Configuration P7an.

\subsubsection{Bug Fixes}

The Software Developer, end user or SRB initiates a SCR form for bug-fix changes. Approval is not required for the software developer to perform bugfix work. The change completion information is supplied by the Software Developer. Testing is supervised and approved by the SA.

\subsubsection{Minor Revisions}

The SCR form is initiated by anyone requesting a change to the software. The approval for revision is granted by the Project Lead. The change completion information is supplied by the Software Developer. Testing is supervised and approved by the SA and Project Lead.

\subsubsection{Major Revisions}

The SCR form is initiated by anyone requesting a change to the software. The approval for revision is granted by the Project Lead. The change completion information is provided by the Software Developer(s) that performs the modifications. Testing is supervised and approved by the SA and the Project Lead. 


\subsection{BACKUP AND RECOVERY}

Secure copies of the source code shall be maintained on floppy disk, removable cartridge, tape, or on a network server (preferably a server that is not physically located in the same building as the software developers). A11 backup media shall be stored in a secure location or a fireproof safe.

A floppy disk is a quick and easy way to make backups and is good for the occasional "oops" scenario (i.e., accidently deleting a file). However, someone could delete the files from the host machine, take the floppies, and delete the files from a network drive. Therefore, the safe shall protect against human intrusions. However, if the building were to burn down, the original machine and floppies would be destroyed and it is unsure how well the fireproof safe would protect the contents. Because of this uncertainty at least one backup shal1 be kept outside of the building to protect against "catastrophic" loss (e.g., fire, bomb). A network server outside of the building would probably be sufficient, although a physical backup (tape or disk) could also be used. 
WHC-SD-WM-CSCM-034, Rev. 0

\subsection{SOFTWARE CHANGE CONTROL}

\subsection{CHANGE IDENTIFICATION}

TWRS Technical Integration staff or end users initiate changes to the software system and communicate change requests by a SCR. The SCR is assigned a unique identifier by the CCA.

\subsection{SCREENING}

Approval for bug fixes are done on a case-by-case basis by the SA to ensure consistency with program direction. Approval for minor and major software revisions is granted by the Project Lead.

\subsection{DEVELOPMENT}

Two separate and distinct environments shall be used for software development and testing. Access to the development environment shall be limited to TWRS Technical Integration personnel involved in the development and control of the specific software.

Al] changes made to the system software shall be pretested in the development environment.

\subsection{TESTING}

The individual test plans shall depend on the criteria defined in the SCRs. Supervision and approval of testing are as described in Section 3.3.

The test environment shal1 be used to perform final acceptance testing and validation of software. Access to the test environment shall be limited to personnel responsible for testing, or their designees.

Test $\mathrm{plans}$ that incorporate test procedures, cases, results, etc., sha11 be developed by TWRS Technical Integration staff for each software package. These Test Plans shall provide documentation that proper testing has been completed and approved.

\subsection{VALIDATION}

Validation to ensure that the change specification is met before system implementation sha11 be done by the CCA and Project Lead.

\subsection{IMPLEMENTATION}

Following testing and approval, the software is made available for use. 


\subsection{STATUS ACCOUNTING}

\section{$5.1 \quad$ RECORDS}

Supporting documents and related changes generated during software development shail be maintained during the life cycle of the software system following the guidance of WHC-CM-3-10, Appendix N. Configuration status at any given point in time is reflected by the online documentation as explained in Section 5.2 and the SCRs that are maintained within the Project Workbook for the related software.

\subsection{TRACKING}

The software changes shall be tracked by software change documentation kept online in the comments section of any affected procedure. The change documentation should include the SCR number, the reason for the change, section(s) of the procedure modified, the name(s) of the software engineer(s) that performed the change, and any other information and comments relevant to the change. A summary area in the source code can be used to catalog the SCR information if comments are also interspersed in the source code to identify areas that have been changed. This status can be shown by displaying the procedures, programs, and tables, or by updating pertinent documentation.

\subsection{ASSESSMENTS}

Assessments shal1 be provided on an ongoing basis by TWRS System Administration with Quality Assurance performing external audits (see WHC-CM-4-2). 
WHC-SD-WM-CSCM-034, Rev. 0

\subsection{REFERENCES}

WHC, 1995, Configuration Management Program Plan, WHC-SD-WM-CM-013, Westinghouse Hanford Company, Richland, Washington.

WHC, 1996, Hanford Site Systems Engineering Manual, WHC-IP-1117, Rev. 1, Westinghouse Hanford Company, Richlan'd, Washington.

WHC-CM-3-10, Software Practices, Westinghouse Hanford Company, Richland, Washington.

WHC-CM-4-2, Qua7ity Assurance Manua7, Westinghouse Hanford Company, Richland, Washington.

WHC-CM-6-1, Standard Engineering Practices, EP-1.12, "Supporting Document Requirements," Westinghouse Hanford Company, Richland, Washington. 
WHC-SD-WM-CSCM-034, Rev. 0

\subsection{DEFINITIONS}

Bug Fixes: Corrections to the software, usually requiring only minor changes or additions to the source code to repair detected bugs (errors).

Minor Revision: Small or minor modifications to the functionality of the software or the interface. Examples of this would be the addition of menu items, buttons, or other Windows' controls. Also included are editorial changes that do not significantly affect the operation of the code/interface.

Major Revision: Significant modifications to the functionality of the software or the interface. Examples include development of new Windows and code development that significantly adds or expands functionality.

Change Control Administrator (CCA): A person that maintains System Change Requests for changes to the software system.

Project Lead: The Software Engineer from the TWRS Technical Integration Organization assigned to provide system support and direction.

Project Workbook: A notebook maintained by the System Administrator for each software package. It contains SCRs, source code listings, test reports, etc. The Project Workbook will be used during audits.

Software Review Board: A board composed of representative users, SA, and Project Lead that recommends future software revisions.

System Administration: The process of maintaining the adherence to documented procedures for system software for daily operation and maintenance. This process is usually done by one key user who acts as the point of contact for a1] requested changes.

System Administrator (SA): The TWRS Technical Integration staff member assigned to administer the software application. This person may also in charge of software development.

System Change Request (SCR): An SCR is a short, usually one page, document that identifies a modification for the software system. A SCR performs two functions: 1) identifies a modification of the software system; or 2) requests preparation of a new report. 
WHC-SD-WM-CSCM-034, Rev. 0

APPENDIX A

RELEVANT FORMS changes:

The following forms will be kept in the Project Workbook to provide tracking of software

- TWRS SYSTEMS ENGINEERING SOFTWARE CHANGE REQUEST

Document that identifies requested changes for the software application.

- TWRS SYSTEMS ENGINEERING SOFTWARE CHANGE LIST

Document that identifies changes made to the software application.

- TWRS SYSTEMS ENGINEERING SOFTWARE TEST \& INCIDENT LOG

Document that tracks testing results of software application.

- TWRS SYSTEMS ENGINEERING SOFTWARE CHANGE ACCEPTANCE CHECKLIST

Document that assures all change procedures are followed and complete before implementation of software changes takes place.

- TWRS SYSTEMS ENGINEERING SOFTWARE CHANGE REQUEST TRACKING LOG

Document that records and tracks all change requests from start to implementation. 
WHC-SD-WM-CSCM-034, Rev. 0

\section{TWRS SE SOFTWARE CHANGE REQUEST}

SYSTEM NAME:

REV NO:

SCR NO:

CHARGE NO:

REQUESTED

CURRENT USER MANUAL REV NO:

COMPLETION:

NEW USER MANUAL REV NO:

TITLE:

DESCRIPTION:

JUSTIFICATION:

INITLATED BY:

DISPOSITION:(APPROVE) (DISAPPROVE) (HOLD)

DISPOSITION

SIGNATURE:

REASON NOT APPROVED:
DATE:

DATE:

DATE:

DATE:

ESTIMATED COST:\$

ESTIMATED COMPLETION:

$1+1$

NEW REV NO:

PORTION OF SYSTEM AFFECTED:

IMPLEMENTATION DETAIL:

WORKED BY:

DATE:

WORK TESTED BY

(VALIDATED):

DATE:

WORK APPROVED

BY:

DATE: 
WHC-SD-WM-CSCM-034, Rev. 0

TWRS SYSTEMS ENGINEERING SOFTWARE CHANGE LIST

\begin{tabular}{|l||}
\hline SCR NUMBER: \\
\hline VERSION NUMBER: \\
\hline 1. \\
2. \\
3. \\
4. \\
5. \\
\hline SERVER CHANG CHANGES: \\
1. \\
2. \\
3. \\
4. \\
5. \\
\hline PROCESSING BATCH FILES: \\
1. \\
2. \\
3. \\
4. \\
5. \\
\hline MISCELLANEOUS: \\
1. \\
2. \\
3. \\
4. \\
5. \\
\hline
\end{tabular}


WHC-SD-WM-CSCM-034, Rev. 0

TWRS SYSTEMS ENGINEERING SOFTWARE TEST/INCIDENT LOG

SCR REF. NUMBER(S):

VERSION UPDATE/NEW VERSION

NUMBER (if applicable):

TEST TITLE:

DESCRIPTION:

TEST PERFORMANCE:

DATE:

\begin{tabular}{|c|c|c|c|c|}
\hline PROGRAMID & THTE & $\begin{array}{l}\text { TEST } \\
\text { CASE/LNCIDENT } \\
\text { EOUND }\end{array}$ & $\begin{array}{l}\text { SATIS }(X / N) \\
\text { BY } \\
\text { (INITIALS) }\end{array}$ & $\begin{array}{r}\text { RESOLUTION } \\
\quad \therefore\end{array}$ \\
\hline & & & & \\
\hline & & & & \\
\hline & & & & \\
\hline & & & & \\
\hline & & & & \\
\hline & & & & \\
\hline & & & & \\
\hline & & & & \\
\hline & & & & \\
\hline & & & & \\
\hline & & & & \\
\hline & & & & \\
\hline & & & & \\
\hline & & & & \\
\hline & & & & \\
\hline & & & & \\
\hline & & & & \\
\hline & & & & \\
\hline & & & & \\
\hline & & & & \\
\hline & & & & \\
\hline
\end{tabular}


WHC-SD-WM-CSCM-034, Rev. 0

TWRS SYSTEMS ENGINEERING SOFTWARE CHANGE ACCEPTANCE CHECKLIST

\begin{tabular}{|l|l|l|}
\hline SCR REF. NUMBER(S): & DATE: & $\begin{array}{l}\text { VERSION UPDATE/NEW VERSION NUMBER } \\
\text { (if applicable): }\end{array}$ \\
\hline
\end{tabular}

\begin{tabular}{||l|l|l|l||}
\hline$\#$ & TASK & SIGNATURE & DATE \\
\hline 1 & SOFTWARE CHANGE COMPLETED & & \\
\hline 2 & FUNCTION TEST CONDUCTED & & \\
\hline 4 & INTEGRATION TEST CONDUCTED & & \\
\hline 5 & "CHANGE LIST" UPDATED & & \\
\hline 6 & $\begin{array}{l}\text { ACCEPTANCE TESTING CONDUCTED AND } \\
\text { DOCUMENTED ON “TEST/INCIDENT LOG" }\end{array}$ & & \\
\hline
\end{tabular}

TEST SUMMARY RESULT:

COMMENTS:

\begin{tabular}{|l|l|}
\hline \multicolumn{1}{|c|}{ ACCEPTANCE OF CHANGE AND READY TO INSTALLA } \\
\hline PROJECT LEAD SIGNATURE: & DATE: \\
\hline SA SIGNATURE & DATE: \\
\hline \hline CCA SIGNATURE & DATE: \\
\hline REQUESTED IMPLEMENTATION DATE & DATE: \\
\hline
\end{tabular}


WHC-SD-WM-CSCM-034, Rev. 0

TWRS SYSTEMS ENGINEERING SCR TRACKING LOG

\begin{tabular}{|c|c|c|c|c|c|c|}
\hline \multirow[t]{2}{*}{ SCR No. } & \multirow[t]{2}{*}{ Title } & \multirow{2}{*}{$\begin{array}{l}\text { System } \\
\text { Name }\end{array}$} & \multirow[t]{2}{*}{ Requester } & \multicolumn{3}{|c|}{ STATUS (Y/N) } \\
\hline & & & & Accepted & Tested & Completed \\
\hline & & & & & & \\
\hline & & & & & & \\
\hline & & & & & & \\
\hline & & & & & & \\
\hline & & & & & & \\
\hline & & & & & & \\
\hline & & & & & & \\
\hline & & & & & & \\
\hline & & & & & & \\
\hline & & & & & & \\
\hline & & & & & & \\
\hline & & & & & & \\
\hline & & & & & & \\
\hline & & & & & & \\
\hline & & & & & & \\
\hline & & & & & & \\
\hline & & & & & & \\
\hline & & & & & & \\
\hline & & & & & & \\
\hline & & & & & & \\
\hline & & & & & & \\
\hline & & & & & & \\
\hline & & & & & & \\
\hline & & & & & & \\
\hline & & & & & & \\
\hline & & & & & & \\
\hline & & & & & & \\
\hline
\end{tabular}




\section{DISTRIBUTION SHEET}

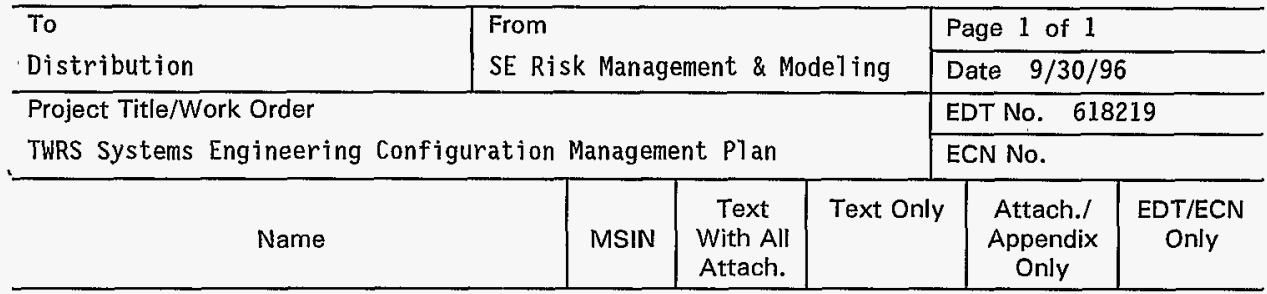

WHC

N. G. Awadal la

B. J. Knutson

B. C. Gneiting

N. J. Graves

A. K. Lee

L. G. Peck

P. E. Porter

J. M. Vann

H6-35

H6-35

H6-35

H6-35

H6-33

H6-35

H6-35

H6-33

$X$
$X$
$X$
$X$
$X$
$X$
$X$
$X$

$\underline{\mathrm{RL}}$

D. J. Francis

K6-51

X

other

Central Files (Original)

A3-88 $X$ 